\title{
CONSTRUCTION AND DEMOLITION WASTE APPLICATIONS AND MAXIMUM DAILY OUTPUT IN SPANISH RECYCLING PLANTS
}

\author{
G. Rodríguez ${ }^{1}$, I.F. Sáez del Bosque ${ }^{2}$, E. Asensio ${ }^{3}$, M.I. Sánchez de Rojas ${ }^{3, a}$, C. Medina ${ }^{2, a}$ \\ ${ }^{1}$ Higher Technical School of Civil Engineering, University of Granada, c/ Severo Ochoa s/n, 18071 \\ Granada, Spain \\ ${ }^{2}$ School of Civil Engineering, University of Extremadura, Research Institute for Sustainable Land \\ Development (INTERRA), Avda. de la Universidad s/n, 10003 Cáceres, Spain \\ 3 "Eduardo Torroja" Institute for Construction Sciences, c/Serrano Galvache, 4, 28033 Madrid, Spain \\ ${ }^{a}$ UEX-CSIC Partnering Unit \\ Corresponding author: grodjer@ugr.es (G. Rodríguez)/ cmedinam@unex.es (C. Medina)
}

\section{ABSTRACT}

The pursuit of construction sustainability and the concomitant use of partially or wholly waste-based eco-materials are driving the study of new applications for recycled aggregate to further and standardise the use of these materials and ensure the survival of the construction and demolition waste (C\&DW) industry. Recycled aggregate (RA), presently used in pavements, fills and embankments and only incipiently to manufacture structural or non-structural concrete, comes to a mere $8.99 \%$ of the natural aggregate extracted in the European Union countries where RA is produced. Against that backdrop, the utility of this study lies in the overview afforded of recycled aggregate typology, the application of the product in bound or unbound materials, the pursuit of new applications, structural or otherwise, and the assessment of daily maximum output by C\&DW management facilities in Spain. The findings show that irrespective of its origin, recycled aggregate most commonly adopts the form of wet mix macadam, gravel or sand used primarily in unbound applications with scantly demanding quality standards. Plant managers contend that recycled aggregate from clean waste can feasibly be used in bound applications that require higher performance materials. Maximum daily output varies widely, with capacity under $200 \mathrm{t} / \mathrm{d}$ in $30 \%$ of the plants. One of the conclusions drawn is that the present management model is in need of revision, with an emphasis on aggregate quality control (certification) and the adoption of technology for separating impurities, pollutants and undesirable materials to improve recycled aggregate quality.

Keywords: recycled aggregates, applications, construction and demolition waste (C\&DW), recycling, Spain

\section{INTRODUCTION}


The enormous amounts of debris generated in construction pose an economically, socially and environmentally unsustainable problem. According to the European Commission's Directorate General, Environment, despite the crisis affecting the industry in recent years, the Union generates a mean of $820 \times 10^{6}$ tonnes of such waste yearly (Gálvez-Martos et al., 2018), adding to the $500 \times 10^{6}$ tonnes produced in the United States and the $1.13 \times 10^{9}$ tonnes in China (Akhtar and Sarmah, 2018). Construction and demolition waste (C\&DW) may be generated in the various stages of a structure's service life: construction, operation (repair and maintenance) and demolition. The greatest volume is associated with the third stage which, depending on the source, is estimated to produce from 10 to 20 (Ulubeyli et al., 2017) and up to 50 (Wu et al., 2016) times the amounts attributable to new construction. Construction debris has a smaller environmental footprint (per $\mathrm{Mg}$ ) than other types of waste, for most of its content is inert. The primary environmental problem associated with C\&DW is the logistics involved in its satisfactory management (transport, energy consumed and particle emissions) and the amount of space occupied: $~ 10000 \mathrm{t}$ of C\&DW is normally equated to a volume of $\sim 6000 \mathrm{~m}^{3}$ (Ding et al., 2016). Its composition, which varies with the origin (civil works, including roads, or residential, academic or industrial facility construction...), comprises differing proportions of stonelike (concrete + masonry, $40 \%$ to $84 \%$; concrete, $12 \%$ to $49 \%$; fired clay/ceramic material, $8 \%$ to $54 \%$; asphalt, $4 \%$ to $26 \%$; and other, $2 \%$ to $9 \%$ ) and non-stone (wood, $2 \%$ to $4 \%$; plastic, $0.1 \%$ to $2 \%$; plaster, $0.2 \%$ to $0.4 \%$; and metal, $0.2 \%$ to $4 \%$ ) components (Gálvez-Martos et al., 2018).

Construction industry sustainability based on the use of eco-materials and the adoption of innovative technologies and more sophisticated manufacturing would entail more efficient use of natural resources and embedded energy and the generation of less debris to induce cleaner production (Ghisellini et al., 2018). Furtherance of clean production favours sustainable development based on the '3Rs', reduce, reuse and recycle (Huang et al., 2018), and contributes effectively to the implementation of alternative growth models, such as the 'green' (Loiseau et al., 2016) or the 'circular' (Leising et al., 2018) economy. Given that construction intrinsically demands large volumes of natural aggregate, one promising approach to attaining the aforementioned goals would be the replacement of natural with recycled aggregates, which would both reduce the impact associated with natural resource mining and eliminate the need for C\&DW landfills. In 2016 the EU-28 produced $2.31 \cdot 10^{9} \mathrm{t}$ of natural and $0.20 \cdot 10^{9} \mathrm{t}$ of recycled aggregate, respectively accounting for $87.46 \%$ and $0.75 \%$ of the total (European Aggregates Association, 2018). As Figure 1 shows, mean recycled aggregate output 
came to $8.99 \%$ of natural aggregate production, excluding countries where such recycled materials are not processed. Those data stand as proof of the capacity of the EU-28 market to absorb larger amounts of recycled aggregates (Deloitte, 2017).

Figure 1. Production of recycled relative to natural aggregate (\%)

That small output is associated with the low recovery rates for C\&DW, along with the present obstacles to using recycled aggregate in construction. Some European countries, such as Denmark, Germany, Netherlands and United Kingdom, reach recovery rates of over $65 \%$, whereas in others, including Finland, Portugal, Spain and Switzerland, rates are under $30 \%$ (Tam et al., 2018), whilst the mean is $46 \%$, far from the $202070 \%$ target (Poulikakos et al., 2017). The obstacles to the use of these new recycled materials include insufficient financial incentives, low quality, customer perception, limited supply and demand, legal constraints, demanding specifications and want of good management models (Tam et al., 2018). The last two factors are very likely the ones that most effectively limit the uptake of recycled aggregate in new eco-materials.

Analyses in Portugal (Coelho and de Brito, 2013a), China (Huang et al., 2018) and Hong Kong (Lu et al., 2016) of the strengths and weaknesses of the C\&DW management models presently in place stress the need to minimise the distance between the site where such debris is generated and the recycling facility and to intensify government involvement. In Spain, the present model features a maximum $30 \mathrm{~km}$ distance between reception and commercialisation of the recycled aggregates, a prevalence of privately owned and run permanent facilities and a need to improve and further the use of C\&DW-based outputs as raw materials in new product manufacture.

Since the nineteen seventies and especially in the last two decades, the international scientific community has extensively researched the viability of reusing C\&DW as a raw material in the construction industry, primarily in cement (Asensio et al., 2016), concrete (Akhtar and Sarmah, 2018) and roads (Poulikakos et al., 2017), studying its inclusion in the respective standards (Tam et al., 2018) (LNEC-E471, NEN 5942, EN 12620, ACI E-701) or formulating recommendations for its use (RILEM, 1994). If implemented, such measures would fell the barriers to the use of recycled aggregate. Focusing on the situation in Spain, the structural concrete code in effect, EHE-08 (Comisión Permanente del Hormigón, 2008), limits the use of recycled coarse aggregate to $20 \%$ in structural concrete, while allowing $100 \%$ in blinding concrete. PG-3 (Ministerio de Fomento, 2015), the country's technical specifications for roads, in turn, envisages the use of recycled aggregate in 
road design and construction (base and sub-base, open-graded aggregate...), provided it meets the requirements laid down for natural aggregate.

This study analyses the products resulting from C\&DW processing and the use in construction of each and determines the maximum daily output in Spain's C\&DW plants, defining the improvements needed in existing management models and technology and the viability of new applications for recycled aggregate.

\section{EXPERIMENTAL}

\subsection{Methodology}

Research for this article was based on the collection, statistical processing, analysis and interpretation of data gathered in a survey conducted in 2013, 2014 and 2015 among the managers of C\&DW processing plants located across the country (Figure 2).

\subsection{Sample}

The first task was to define the sample of the population to be surveyed. A database of companies engaging in C\&DW processing was consequently built from the information published online by the Asociación Nacional de Gestores de RCD (GERD: national association of C\&DW managers) and the autonomous regions' environmental affairs departments on their respective websites. That was followed by snowball sampling, in which the data in the initial base were reviewed and information from other companies with similar characteristics added. The resulting sample contained a total of 127 C\&DW management facilities. A questionnaire was subsequently emailed, faxed or posted to those firms, in keeping with the procedures deployed in earlier research (Duran et al., 2006; Lu and Yuan, 2010; Saez et al., 2013). In all, 49 companies sited in nearly all of Spain's regions (see Figure 2) returned the completed questionnaires, for a $39 \%$ response rate. That percentage is higher than obtained in other studies (De Melo et al., 2011; Yu et al., 2013) and may be deemed acceptable for the construction industry (Yu et al., 2013).

Figure 2. Geographic distribution of respondent facilities

The replies were coded for subsequent statistical analysis and processed with SPSS statistical software. The data discussed below are not weighted by each plant's total output.

\section{RESULTS AND DISCUSSION}

\subsection{Products manufactured from C\&DW}


The recycled C\&DW products graphed in Figure 3 are shown for all three types of waste used: clean (consisting in concrete only), mixed or dirty. The materials were classified on the grounds of their characteristics (grain size distribution, presence of impurities and so on) as per the provisions of Spain's structural concrete code EHE-08 and its technical specifications for roads PG-3.

Three types of waste received at the plants were identified: clean debris from crushed structural concrete or milled pavement; mixed waste consisting in a non-uniform blend of concrete, fired clay/ceramic materials, asphalt and similar; and dirty refuse containing in addition to C\&DW, other types of waste such as topsoil, household appliances or mattresses. Practice in terms of types of refuse received at Spanish C\&DW plants differs from that in other countries such as Portugal (Coelho and de Brito, 2013b), where these facilities receive only mixed or clean debris, or China where they take in inert, non-inert and polluted waste (Ghisellini et al., 2018). The presence of mixed or dirty waste or both can be primarily attributed to two factors: the prevalence of conventional techniques or explosives to demolish existing structures and the much less frequent deployment of selective procedures that recover higher proportions of material, favouring valorisation and raising the end quality of the recycled material (Ghisellini et al., 2018); and the origin of construction and demolition waste, which as in the United States is primarily building ( $44 \%)$, followed by roads and bridges ( 31\%) and others ( 25\%).

Figure 3 shows that the products most frequently processed included wet mix macadam (32.65\%), sand $(26.53 \%)$ and gravel $(26.53 \%)$ and to a lesser extent drainage fill $(18.4 \%)$, aggregate for concrete (16.3\%) and 'tolerable' $12.2 \%$ ) and 'selected' (10.2 \%) soil. A third category of recycled materials account observed consisted in 'adequate' soils, aggregate for hot mix asphalt (HMA) and similar. All these granular materials exhibited a variable particle size distribution ranging from $0 \mathrm{~mm}$ to $80 \mathrm{~mm}$, depending on the end product sought. Those maximum and minimum values were consistent with the distribution of the recycled aggregate $(0 \mathrm{~mm}$ to $70 \mathrm{~mm}$ ) delivered by permanent C\&DW recycling plants in Italy (Bassan and Quattrone, 2013).

Figure 3. Products manufactured with C\&DW

Further to the data on C\&DW treatment plant products listed in Table 1 by type of waste (clean, mixed or dirty), clean C\&DW was used primarily as a raw material for wet mix macadam, gravel and sand, all with percentages of over $20 \%$. The same frequency distribution was found for mixed C\&DW products.

Table 1. C\&DW products by type of waste 
Dirty waste, in turn, yielded gravel, sand, wet mix macadam, 'tolerable' and 'marginal' soil, although the percentages were lower than with the other two sources $(<4 \%)$.

The prevalence of wet mix macadam, gravel and sand irrespective of the waste type (clean, dirty or mixed) was an indication that plants had geared their procedures to these products for which market demand was greatest and for which manufacture could be most readily standardised.

The table also highlights the importance of sorting during collection to deliver quality products: the frequency of production of recycled materials (aggregate for concrete, sand, gravel, natural opengraded aggregate) for applications subject to strict requirements was highest with clean C\&DW, followed by mixed and dirty waste, in that order. The rate of production of higher quality recycled materials could be raised by improving the technology presently in place in management facilities (Duan et al., 2015), with the introduction of near-infrared sorting for mixed waste, for instance (Vegas et al., 2015).

\subsection{Present applications of recycled aggregate from C\&DW}

The two main uses for recycled aggregate (Figure 4), irrespective of whether it was produced from clean, mixed or dirty waste, were localised fill (67.3\%) and granular bases and sub-bases in pavements $(63.3 \%)$, primarily in rural roads where lower traffic intensity calls for less strict quality control. The third most common usage was drainage fill in urban hardscaping, with a frequency of $51 \%$.

The use of such aggregate as localised fill in public or private land is routine practice in Chinese cities and Hong Kong (Ghisellini et al., 2018). A Belgian study (Vrijders and Desmyter, 2013) also found pavement granular bases, sub-bases and fill to be common applications, whilst in Germany around 90 $\%$ of recycled aggregate has been reported to serve as pavement under-layers (Mueller, 2013).

Figure 4. C\&DW-based recycled aggregates: uses

The data in Table 2 on recycled aggregate applications by type of C\&DW (clean, mixed or dirty) show that the frequency of use was closely related to the quality of the end product and therefore to the proportion of impurities in the raw waste. This is an issue of particular significance throughout the country because the technology in place at C\&DW management facilities is elementary, with manual sorting of undesirable stone-like elements (ceramics, asphalt) and other pollutants removed by 
density-difference systems (plaster), float and sink techniques, windshifters (timber, plastic) or magnetic separators.

Table 2. Application of recycled aggregate from clean, mixed and dirty C\&DW Aggregate produced from clean C\&DW was most frequently commercialised for granular bases and sub-bases in pavements $(22.4 \%)$, drainage fill (14.3\%), localised fill (12.2\%) and embankments $(8.2 \%)$. The implication of those findings is that despite the enormous valorisation potential of this recycled material, it is found primarily in unbound applications that are regulated more leniently than structural materials. That is consistent with practice in Europe as a whole, where recycled aggregate is preferably earmarked for earthworks, fill and road sub-bases (Gálvez-Martos et al., 2018), North America (Razaqpur and Fathifazl, 2013), where it is used for non-structural applications such as backfill, embankments, drainage fill, pavement bases and sub-bases and China (Duan et al., 2015), where the foremost application is fill. The same model prevails in countries such as Vietnam (Lockrey et al., 2016), where the demand for recycled materials is low and recycling culture nearly absent among the actors involved (contractors, government and engineers).

Unbound materials such as localised and drainage fill (both at $12.2 \%$ ), granular sub-bases in roads $(8.2 \%)$ and embankments $(6.1 \%)$ were likewise the most frequent applications for mixed C\&DWbased aggregate (Table 2). That is in line with reports for other EU Member States (Vegas et al., 2015), where such recycled products are used unbound in civil works (embankments, sub-bases and fill for roads) for which requirements are less demanding. Some authors, however (Gálvez-Martos et al., 2018) note that this type of recycled aggregate might be apt for non-structural uses in building and civil construction.

Aggregate derived from dirty C\&DW was used less frequently than the other two types of material, with application confined to localised fill $(2.0 \%)$ and granular sub-bases for rural roads $(2.0 \%)$ with lighter traffic loads than in trunk roads

Clean and mixed C\&DW-based aggregate was scantly used $(<2 \%)$ in bound applications (concrete, mortar and hot mix asphalt). That statistic is consistent with international practice, even though the use of recycled concrete and some mixed (depending on their composition) recycled aggregates is regulated in certain standards.

\subsection{Feasibility of new applications for C\&DW recycled aggregate}


Figure 5 illustrates the respondent-suggested feasibility of other applications for recycled aggregate, irrespective of the type of raw waste from which it is sourced. The frequency of each specific application was calculated relative to the total number of respondent facilities (49). Plant managers contended that recycled products, while usable primarily in unbound applications, with over $16 \%$ of respondents identifying each type, could also meet the more demanding requirements for bound applications (concrete>mortar hot mix asphalt).

Figure 5. Feasibility of other applications for C\&DW recycled aggregate (the data refer to potential uses identified by respondents, i.e., not in place at the time of the survey; for instance, the four facilities identifying concrete manufacture as a possible application were not included in the seven shown in Figure 3)

The data on other uses for recycled aggregate not presently implemented given in Table 3 by type of waste show that managers deemed that recycled concrete aggregate could be used to manufacture concrete $(22.4 \%)$, mortar $(12.2 \%)$ and hot mix asphalt $(12.2 \%)$. Other authors reporting similar results (Tam and Tam, 2006) also identified concrete and asphalt concrete as possible products of concrete demolition waste. Such findings imply that the low frequency of use of recycled materials in such applications can be attributed to unawareness of their properties on the part of engineers and contractors, consumer mistrust and the lack of a specific national legislation governing such materials.

Table 3. Feasibility of new applications for recycled aggregate Managers were less prone to propose bound applications for mixed recycled aggregate, due primarily to its compositional non-uniformity. That notwithstanding, a number of research teams (Sáez del Bosque et al., 2017), (Medina et al., 2015), (Lopez-Uceda et al., 2016) (Yang et al., 2011) have reported promising laboratory-scale results for the use of these new raw materials in structural and non-structural concrete. Their conclusions are in line with other those of other studies, showing that mixed recycled aggregate with a concrete, mortar and unbound aggregate content of $\geq 70 \%$ and fired clay material content of $\leq 30 \%$ can be used to manufacture structural and non-structural concrete and hot mix asphalt (Martins, 2013); or that such aggregate (normally with at least $50 \mathrm{wt} \%$ of concrete) is apt for non-structural concrete applications in building and civil construction, although not for precast concrete elements.

More intense valorisation in unbound applications (fill) was deemed to be possible for mixed C\&DW by $20.4 \%$ of recycling facility managers and for dirty waste by $8.1 \%$. According to these managers, the 
main constraint for valorising mixed C\&DW for other uses with stricter performance requirements is the presence of plaster, a finding reported by earlier authors (Gálvez-Martos et al., 2018).

\subsection{C\&DW recycled aggregate quality control}

The data on quality control tests conducted at C\&DW recycling facilities graphed in Figure 6 reveal that $28.6 \%$ ran no tests on the recycled aggregates processed. The remaining plants reported testing by type of C\&DW (30.6\%), product $(6.1 \%)$ or indistinctly regardless of product or waste type $(30.6 \%)$. The inference is that recycled aggregate is normally commercialised under no seal guaranteeing quality or certifying its physical, chemical or mechanical properties. Other authors (Silva et al., 2017) also found most recycling plant product offerings to consist in uncertified aggregate, a shortcoming that severely narrows its commercial potential.

Figure 6. Quality control testing in C\&DW recycling facilities

Quality control and certification must be systematised to guarantee compliance with certain minimum requisites or specifications, in keeping with product use or application. The factors affecting the production and use of certified recycled aggregate include price, legislation, societal perception, technological process, location, use and quality (Trevorrow and Lyne 1998). For instance, the lower price of certified recycled than certified natural aggregate is a sizeable deterrent for production in recycling facilities, given the higher cost of processing the former than the latter.

Further to the values in Table 4 on C\&DW facility testing by construction and operating arrangements, in Spain construction and operation were reported to account for $69.4 \%$ of the total. The lack of any correlation whatsoever between testing and C\&DW facility management model could be attributed to the present use of recycled aggregate (see section 3.2) in applications with low performance requirements.

Table 4. Quality control testing by C\&DW facility operational status The managers also reported that testing was conducted at the beginning of the production stream and not repeated randomly during the process to systematically control aggregate quality. If such tests were performed, the physical, chemical and mechanical properties of the products could inform recommendations for possible bound or unbound uses (see sections 3.2 and 3.3).

At this time the use of recycled aggregates for applications subject to strict quality standards cannot be guaranteed except in special situations where specific verification or certification testing is conducted. 
Hence the need for efforts to control aggregate production to encourage its wider use in such applications.

\subsection{Tests conducted on recycled C\&DW}

Of the 33 facilities conducting tests, $63.3 \%$ analysed grain size distribution and around $50 \%$ ran the sand equivalent test. Less commonly ( $\leq 20 \%)$, tests were conducted to determine compositional, physical or chemical properties, such as involved in the classification of recycled coarse aggregate components (concrete, asphalt, fired clay materials), sulfur content, plaster and light material content, surface impurities or proportion of clay lumps.

Determination of grain size distribution in recycled aggregate by nearly two-thirds of the facilities was attributable to the use of that parameter as a criterion for classifying the end product and to the fact that particle size plays an essential part in both bound and unbound applications, but particularly in the former (Di Maria et al., 2016). In concrete, for instance, aggregate grain size distribution affects workability, porosity, permeability, strength and durability.

Table 5. Tests conducted on recycled C\&DW

Other tests found to be conducted with intermediate frequency (50\% to $20 \%$ ) included the study of plasticity (Atterberg limit), abrasion resistance (Los Angeles coefficient), shape (flakiness index), determination of optimal compaction moisture (normal or modified Proctor), bearing strength (CBR) and chemical analyses (soluble salts, sulfates, chlorides and organic matter).

The frequency of these tests might be explained by the applications for recycled products deriving from the waste management processes described in section 3.2. Table 5 reveals that none of the facilities determined recycled aggregate water absorption or resistance to temperature change, given its essentially marginal use in concrete manufacture. The implementation of such tests in all C\&DW facilities would boost recycled aggregate use both in the present applications (section 3.2 ) and in applications with more demanding requirements (section 3.3), for earlier studies (Silva et al., 2014) showed that the physical properties of recycled aggregate, irrespective of its size and composition, are predictably related to performance. Therefore, a performance-based classification readily understandable to professionals and the industry could be established on the grounds of test results.

\subsection{Change in recycled aggregate characteristics over time}


Of the 49 respondent facilities, only 13 replied to the question on the variations in recycled aggregate characteristics over time. On the whole, the processed aggregate was deemed to be very uniform, with no mention of any specific characteristic that changed.

Table 6. Variation in characteristics over time

The facilities could furnish no detailed data for, as noted in the preceding section, their production was not systematically controlled.

\subsection{Maximum C\&DW facility output}

The frequency distribution of Spanish C\&DW facilities by maximum daily output (Figure 7) showed that production at the time of the survey was under $500 \mathrm{t} / \mathrm{d}$ in around $60 \%$ of the plants, whilst $29.2 \%$ produced from $500 \mathrm{t} / \mathrm{d}$ to $2000 \mathrm{t} / \mathrm{d}, 9.8 \%$ from $2001 \mathrm{t} / \mathrm{d}$ to $5000 \mathrm{t} / \mathrm{d}$ and $2.4 \% 5000 \mathrm{t} / \mathrm{d}$ to $10000 \mathrm{t} / \mathrm{d}$. The heterogeneity observed was attributable to a lack of nation-, region-, or province-wide planning to site facilities in keeping with population density and therefore the volume of waste generated. Plant output is likewise affected by factors such as construction ratios, waste pit prices, aggregate availability and price, legislation and inter-facility competition (Coelho and de Brito, 2013b).

Figure 7. C\&DW facility distribution by daily output (Note: data for 41 respondent facilities)

Most of the plants across the country reported output figures lower than the mean for a permanent facility (100 t/h to $350 \mathrm{t} / \mathrm{h}$ or $800 \mathrm{t} / \mathrm{d}$ to $2800 \mathrm{t} / \mathrm{d}$ ) (Ulubeyli et al., 2017) and lower than the minimum output estimated for plants sited in Brazilian towns/cities ( $733 \mathrm{t} / \mathrm{d}$ to $1372 \mathrm{t} / \mathrm{d})$ or the Lisbon, Portugal metropolitan area (3456 t/d) (De Melo et al., 2011). The initial investment for a plant with an output of $20 \mathrm{t} / \mathrm{h}$ is estimated to be $€ 250000$, for $50 \mathrm{t} / \mathrm{h}, € 600000$ and for $100 \mathrm{t} / \mathrm{h}$, $€ 800000$ (Ulubeyli et al., 2017), while output values of under $20 \mathrm{t} / \mathrm{h}(\approx 160 \mathrm{t} / \mathrm{d}$, assuming an $8 \mathrm{~h}$ day) would be economically unsound due to low productivity and the low market price for the end product (Nunes et al., 2007).

\section{CONCLUSIONS}

The conclusions drawn from this study are listed below.

- The recycled materials most commonly produced at Spanish C\&DW facilities are wet mix macadam, gravel and sand, irrespective of the type of waste processed.

- Recycled aggregate is used primarily in unbound applications governed by fairly lenient quality standards such as localised fill, granular bases and sub-bases in pavement and drainage fill.

- Facility managers deem clean recycled aggregate in particular to be usable in more strictly regulated bound applications (concrete, mortar and hot mix asphalt). 
- Recycled aggregate continues to be only marginally used, either because the legislation is outdated or because natural aggregate continues to compete with the recycled product, hindering its wider use.

- Recycled aggregate quality is controlled sporadically and only partially. In-house quality systems are needed to certify and favour end product commercialisation.

- Maximum daily output in approximately $30 \%$ of the C\&DW facilities is below the costeffectiveness threshold defined in the literature.

The present management model is in need of revision, in particular as regards aggregate quality control, an imperative to establishing a performance-application table that would further the use of C\&DW as a raw material in new product manufacture. The institution of technologies to separate impurities, pollutants or undesirable materials should also be contemplated to improve the quality of recycled aggregate.

\section{Acknowledgements}

This study was funded by the Spanish Ministry of the Economy and Competitiveness under project ref. BIA2016-76643-C3-1-R.

\section{References}

Akhtar, A., Sarmah, A.K., 2018. Construction and demolition waste generation and properties of recycled aggregate concrete: A global perspective. J. Clean Prod. 186, 262-281. https://doi.org/10.1016/j.jclepro.2018.03.085.

Asensio, E., Medina, C., Frías, M., Rojas María Isabel, S., 2016. Characterization of Ceramic-Based Construction and Demolition Waste: Use as Pozzolan in Cements. J. Am. Ceram. Soc. 99(12), 41214127. https://doi.org/10.1111/jace.14437.

Bassan, M., Quattrone, M., 2013. Overview Regarding Construction and Demolition Waste in Several Countries. Recycling in Italy: overview regarding construction and demolition waste., in: Vázquez, E. (Ed.) Progress of Recycling in the Built Environment. Springer, Netherlands, pp. 115-130.

Coelho, A., de Brito, J., 2013a. Economic viability analysis of a construction and demolition waste recycling plant in Portugal - part I: location, materials, technology and economic analysis. J. Clean Prod. 39, 338-352. https://doi.org/10.1016/j.jclepro.2012.08.024. 
Coelho, A., de Brito, J., 2013b. Environmental analysis of a construction and demolition waste recycling plant in Portugal - Part II: Environmental sensitivity analysis. Waste Manage. 33(1), 147-161. https://doi.org/10.1016/j.wasman.2012.09.004.

Comisión Permanente del Hormigón, 2008. Instrucción Hormigón Estructural. EHE-08, Primera Edición ed. Ministerio de Fomento. Centro de Publicaciones, Madrid.

De Melo, A.B., Goncalves, A.F., Martins, I.M., 2011. Construction and demolition waste generation and management in Lisbon (Portugal). Resour. Conserv. Recycl. 55(12), 1252-1264. https://doi.org/10.1016/j.resconrec.2011.06.010.

Deloitte, 2017. Study on Resource Efficient Use of Mixed Wastes, Improving management of construction and demolition waste - Final Report, in: European Commision, D.E. (Ed.).

Di Maria, F., Bianconi, F., Micale, C., Baglioni, S., Marionni, M., 2016. Quality assessment for recycling aggregates from construction and demolition waste: An image-based approach for particle size estimation. Waste Manage. 48, 344-352. https://doi.org/10.1016/j.wasman.2015.12.005.

Ding, Z., Wang, Y., Zou, P.X.W., 2016. An agent based environmental impact assessment of building demolition waste management: Conventional versus green management. J. Clean Prod. 133, 11361153. https://doi.org/10.1016/j.jclepro.2016.06.054.

Duan, H., Wang, J., Huang, Q., 2015. Encouraging the environmentally sound management of C\&D waste in China: An integrative review and research agenda. Renew. Sust. Energ. Rev. 43, 611-620. https://doi.org/10.1016/j.rser.2014.11.069.

Duran, X., Lenihan, H., O'Regan, B., 2006. A model for assessing the economic viability of construction and demolition waste recycling - the case of Ireland. Resour. Conserv. Recycl. 46(3), 302-320. https://doi.org/10.1016/j.resconrec.2005.08.003.

European Aggregates Association, 2018. Statistics: Estimates of aggregates production data 2016.

Ghisellini, P., Ji, X., Liu, G., Ulgiati, S., 2018. Evaluating the transition towards cleaner production in the construction and demolition sector of China: A review. J. Clean Prod. 195, 418-434. https://doi.org/10.1016/j.jclepro.2018.05.084.

Gálvez-Martos, J.-L., Styles, D., Schoenberger, H., Zeschmar-Lahl, B., 2018. Construction and demolition waste best management practice in Europe. Resour. Conserv. Recycl. 136, 166-178. https://doi.org/10.1016/j.resconrec.2018.04.016. 
Huang, B., Wang, X., Kua, H., Geng, Y., Bleischwitz, R., Ren, J., 2018. Construction and demolition waste management in China through the 3R principle. Resour. Conserv. Recycl. 129, 36-44. https://doi.org/10.1016/j.resconrec.2017.09.029.

Leising, E., Quist, J., Bocken, N., 2018. Circular Economy in the building sector: Three cases and a collaboration tool. J. Clean Prod. 176, 976-989. https://doi.org/10.1016/j.jclepro.2017.12.010.

Lockrey, S., Nguyen, H., Crossin, E., Verghese, K., 2016. Recycling the construction and demolition waste in Vietnam: opportunities and challenges in practice. J. Clean Prod. 133, 757-766. https://doi.org/10.1016/j.jclepro.2016.05.175

Loiseau, E., Saikku, L., Antikainen, R., Droste, N., Hansjürgens, B., Pitkänen, K., Leskinen, P., Kuikman, P., Thomsen, M., 2016. Green economy and related concepts: An overview. J. Clean Prod. 139, 361-371. https://doi.org/10.1016/j.jclepro.2016.08.024.

Lopez-Uceda, A., Ayuso, J., Lopez, M., Jimenez, J.R., Agrela, F., Sierra, M.J., 2016. Properties of Non-Structural Concrete Made with Mixed Recycled Aggregates and Low Cement Content. Materials 9(2). https://doi.org/10.3390.

Lu, W., Chen, X., Ho, D.C.W., Wang, H., 2016. Analysis of the construction waste management performance in Hong Kong: the public and private sectors compared using big data. J. Clean Prod. 112, Part 1, 521-531. https://doi.org/10.1016/j.jclepro.2015.06.106.

Lu, W.S., Yuan, H.P., 2010. Exploring critical success factors for waste management in construction projects of China. Resour. Conserv. Recycl. 55(2), 201-208. https://doi.org/10.1016/j.resconrec.2010.09.010

Martins, I., 2013. Overview Regarding Construction and Demolition Waste in Several Countries. Recycling in Portugal: overview of CDW, in: Vázquez, E. (Ed.) Progress of Recycling in the Built Environment. Springer, Nerthelands, pp. 134 - 144.

Medina, C., Zhu, W., Howind, T., Frías, M., Sánchez de Rojas, M.I., 2015. Effect of the constituents (asphalt, clay materials, floating particles and fines) of construction and demolition waste on the properties of recycled concretes. Constr. Build. Mater. 79, 22-33. https://doi.org/10.1016/j.conbuildmat.2014.12.070.

Menegaki, M., Damigos, D., 2018. A review on current situation and challenges of construction and demolition waste management. Current Opinion in Green and Sustainable Chemistry 13, 8-15. https://doi.org/10.1016/j.cogsc.2018.02.010 
Ministerio de Fomento, 2015. Orden FOM/2523/2014, de 12 de diciembre, por la que se actualizan determinados artículos del pliego de prescripciones técnicas generales para obras de carreteras y puentes (PG-3/75), relativos a materiales básicos, a firmes y pavimentos, y a señalización, balizamiento y sistemas de contención de vehículos. Boletín Oficial del Estado (BOE), ㄲo3, Madrid.

Mueller, A., 2013. Overview Regarding Construction and Demolition Waste in Several Countries. Recycling in Germany: Overview regarding CDW in Germany, in: Vázquez, E. (Ed.) Progress of Recycling in the Built Environment. Springer, Netherlands, pp. 106-115.

Nunes, K.R.A., Mahler, C.F., Valle, R., Neves, C., 2007. Evaluation of investments in recycling centres for construction and demolition wastes in Brazilian municipalities. Waste Manage. 27(11), 1531-1540. https://doi.org/10.1016/j.wasman.2006.09.007.

Poulikakos, L.D., Papadaskalopoulou, C., Hofko, B., Gschösser, F., Cannone Falchetto, A., Bueno, M., Arraigada, M., Sousa, J., Ruiz, R., Petit, C., Loizidou, M., Partl, M.N., 2017. Harvesting the unexplored potential of European waste materials for road construction. Resour. Conserv. Recycl. 116, 32-44. https://doi.org/10.1016/j.resconrec.2016.09.008.

Razaqpur, G., Fathifazl, G., 2013. Overview Regarding Construction and Demolition Waste in Several Countries. Recycling in North America: state of the art of RCA concrete in North America, in: Vázquez, E. (Ed.) Progress of Recycling in the Built Environment. Springer, Netherlands, pp. 52-58.

RILEM, 1994. Specifications for concrete with recycled aggregates. Mater. Struct. 27(173), 557-559. https://doi.org/10.1007/BF02473217.

Rodríguez, G., Medina, C., Alegre, F.J., Asensio, E., Sánchez de Rojas, M.I., 2015. Assessment of Construction and Demolition Waste plant management in Spain: in pursuit of sustainability and ecoefficiency. J. Clean Prod. 90, 16-24. https://doi.org/10.1016/j.jclepro.2014.11.067.

Saez, P.V., Merino, M.D., Gonzalez, A.S., Porras-Amores, C., 2013. Best practice measures assessment for construction and demolition waste management in building constructions. Resour. Conserv. Recycl. 75, 52-62. https://doi.org/10.1016/j.resconrec.2013.03.009.

Silva, R.V., de Brito, J., Dhir, R.K., 2014. Properties and composition of recycled aggregates from construction and demolition waste suitable for concrete production. Constr. Build. Mater. 65, 201-217. https://doi.org/10.1016/j.conbuildmat.2014.04.117. 
Silva, R.V., de Brito, J., Dhir, R.K., 2017. Availability and processing of recycled aggregates within the construction and demolition supply chain: A review. J. Clean Prod. 143, 598-614. https://doi.org/10.1016/j.jclepro.2016.12.070.

Sáez del Bosque, I.F., Zhu, W., Howind, T., Matías, A., Sánchez de Rojas, M.I., Medina, C., 2017. Properties of interfacial transition zones (ITZs) in concrete containing recycled mixed aggregate. Cem. Concr. Compos. 81, 25-34. https://doi.org/10.1016/j.cemconcomp.2017.04.011.

Tam, V.W.Y., Soomro, M., Evangelista, A.C.J., 2018. A review of recycled aggregate in concrete applications (2000-2017). Constr. Build. Mater. 272-292. https://doi.org/10.1016/j.conbuildmat.2018.03.240.

Tam, V.W.Y., Tam, C.M., 2006. A review on the viable technology for construction waste recycling. Resour. Conserv. Recycl. 47(3), 209-221. https://doi.org/10.1016/j.resconrec.2005.12.002.

Trevorrow, A., Lyne, T., 1998. Recycled aggregate markets: where to Start?, in: Dhir, R.K., Henderson, N.A., Limbachiya, M.C. (Ed.) Proceedings of the International Symposium on Sustainable Construction: Use of Recycled Concrete Aggregate. Thomas Telford, London, UK, pp. 493-504.

Ulubeyli, S., Kazaz, A., Arslan, V., 2017. Construction and Demolition Waste Recycling Plants Revisited: Management Issues. Procedia Engineering 172, 1190-1197. https://doi.org/10.1016/j.proeng.2017.02.139.

Vegas, I., Broos, K., Nielsen, P., Lambertz, O., Lisbona, A., 2015. Upgrading the quality of mixed recycled aggregates from construction and demolition waste by using near-infrared sorting technology. Constr. Build. Mater. 75, 121-128. https://doi.org/10.1016/j.conbuildmat.2014.09.109.

Vrijders, J., Desmyter, J., 2013. Overview Regarding Construction and Demolition Waste in Several Countries. Recycling in Belgium: a overiview of the present situation in Belgium from the recycling industry and research about CDW, in: Vázquez, E. (Ed.) Progress of Recycling in the Built Environment. Springer, Netherlands, pp. 37-42.

Wu, H., Duan, H., Zheng, L., Wang, J., Niu, Y., Zhang, G., 2016. Demolition waste generation and recycling potentials in a rapidly developing flagship megacity of South China: Prospective scenarios and implications. Construction and Building Materials 113, 1007-1016.

Yang, J., Du, Q., Bao, Y., 2011. Concrete with recycled concrete aggregate and crushed clay bricks. Constr. Build. Mater. 25(4), 1935-1945. https://doi.org/10.1016/j.conbuildmat.2010.11.063. 
Yu, A.T.W., Poon, C.S., Wong, A., Yip, R., Jaillon, L., 2013. Impact of Construction Waste Disposal Charging Scheme on work practices at construction sites in Hong Kong. Waste Manage. 33(1), 138146. https://doi.org/10.1016/j.wasman.2012.09.023. 
Table 1. C\&DW products by type of waste

\begin{tabular}{|c|c|c|c|c|c|c|}
\hline \multirow{2}{*}{ Product } & \multicolumn{2}{|c|}{ Clean C\&DW } & \multicolumn{2}{|c|}{ Mixed C\&DW } & \multicolumn{2}{|c|}{ Dirty C\&DW } \\
\hline & No. plants & $\%$ & No. plants & $\%$ & No. plants & $\%$ \\
\hline $\begin{array}{l}\text { Aggregate for } \\
\text { concrete }\end{array}$ & 4 & 8.2 & 1 & 2.0 & 0 & 0.0 \\
\hline Sand & 10 & 20.4 & 7 & 14.3 & 1 & 2.0 \\
\hline Wet mix macadam & 17 & 34.7 & 9 & 18.4 & 1 & 2.0 \\
\hline $\begin{array}{l}\text { Natural open-graded } \\
\text { aggregate }\end{array}$ & 2 & 4.1 & 2 & 4.1 & 0 & 0.0 \\
\hline Selected soil & 3 & 6.1 & 2 & 4.1 & 0 & 0.0 \\
\hline Adequate soil & 1 & 2.0 & 1 & 2.0 & 0 & 0.0 \\
\hline Tolerable soil & 3 & 6.1 & 1 & 2.0 & 1 & 2.0 \\
\hline Marginal soil & 1 & 2.0 & 1 & 2.0 & 1 & 2.0 \\
\hline Inadequate soil & 0 & 0.0 & 0 & 0.0 & 0 & 0.0 \\
\hline Drainage fill & 4 & 8.2 & 3 & 6.1 & 0 & 0.0 \\
\hline $\begin{array}{l}\text { Aggregate for hot } \\
\text { mix asphalt }\end{array}$ & 0 & 0.0 & 0 & 0.0 & 0 & 0.0 \\
\hline Gravel & 11 & 22.4 & 7 & 14.3 & 2 & 4.1 \\
\hline Dry bound macadam & 4 & 8.2 & 2 & 4.1 & 0 & 0.0 \\
\hline Other & 4 & 8.2 & 4 & 8.2 & 2 & 4.1 \\
\hline Total & 49 & - & 49 & - & 49 & - \\
\hline
\end{tabular}

Table 2. Application of recycled aggregate from clean, mixed and dirty C\&DW

\begin{tabular}{|c|c|c|c|c|c|c|}
\hline \multirow{2}{*}{ Application } & \multicolumn{2}{|c|}{ Clean C\&DW } & \multicolumn{2}{|c|}{ Mixed C\&DW } & \multicolumn{2}{|c|}{ Dirty C\&DW } \\
\hline & No. plants & $\%$ & No. plants & $\%$ & No. plants & $\%$ \\
\hline $\begin{array}{l}\text { Structural/non-structural concrete } \\
\text { manufacture }\end{array}$ & 1 & 2.0 & 1 & 2.0 & 0 & 0.0 \\
\hline Mortar manufacture & 1 & 2.0 & 0 & 0.0 & 0 & 0.0 \\
\hline $\begin{array}{l}\text { Granular bases and sub-bases in } \\
\text { pavements }\end{array}$ & 11 & 22.4 & 4 & 8.2 & 1 & 2.0 \\
\hline Embankments & 4 & 8.2 & 3 & 6.1 & 0 & 0.0 \\
\hline Localised fill & 6 & 12.2 & 6 & 12.2 & 1 & 2.0 \\
\hline Drainage fill & 7 & 14.3 & 6 & 12.2 & 0 & 0.0 \\
\hline Hot mix asphalt manufacture & 0 & 0.0 & 0 & 0.0 & 0 & 0.0 \\
\hline Breakwaters & 0 & 0.0 & 0 & 0.0 & 0 & 0.0 \\
\hline Ballast & 1 & 2.0 & 0 & 0.0 & 0 & 0.0 \\
\hline Other & 1 & 2.0 & 3 & 6.1 & 0 & 0.0 \\
\hline Total & 49 & - & 49 & - & 49 & - \\
\hline
\end{tabular}


Table 3. Feasibility of new applications for recycled aggregate

\begin{tabular}{|l|c|c|c|c|c|c|}
\hline \multirow{2}{*}{ Product } & \multicolumn{2}{|c|}{ Clean C\&DW } & \multicolumn{2}{c|}{ Mixed C\&DW } & \multicolumn{2}{c|}{ Dirty C\&DW } \\
\cline { 2 - 7 } & No. plants & $\%$ & No. plants & $\%$ & No. plants & $\%$ \\
\hline Concrete manufacture & 11 & 22.4 & 1 & 2.0 & 0 & 0.0 \\
Mortar manufacture & 6 & 12.2 & 1 & 2.0 & 0 & 0.0 \\
$\begin{array}{l}\text { Granular bases and } \\
\text { sub-bases in } \\
\text { pavements }\end{array}$ & 9 & 18.4 & 5 & 10.2 & 0 & 0.0 \\
Embankments & 4 & 8.2 & 4 & 8.2 & 3 & 6.1 \\
Localised fill & 8 & 16.3 & 10 & 20.4 & 4 & 8.2 \\
Drainage fill & 7 & 14.3 & 5 & 10.2 & 2 & 4.1 \\
Hot mix asphalt & 6 & 12.2 & 0 & 0.0 & 0 & 0.0 \\
manufacture & 1 & 2.0 & 2 & 4.1 & 0 & 0.0 \\
Breakwaters & 2 & 4.1 & 1 & 2.0 & 0 & 0.0 \\
Ballast & 1 & 2.0 & 2 & 4.1 & 0 & 0.0 \\
Other & $\mathbf{4 9}$ & - & $\mathbf{4 9}$ & - & $\mathbf{4 9}$ & - \\
Total & & & & & \\
\hline
\end{tabular}

Table 4. Quality control testing by C\&DW facility operational status

\begin{tabular}{|l|c|c|c|c|c|c|c|c|c|c|c|c|c|}
\hline & $\begin{array}{c}\text { Private } \\
\text { construction } \\
\text { and } \\
\text { operation }\end{array}$ & \multicolumn{2}{|c|}{$\begin{array}{c}\text { Public } \\
\text { construction, } \\
\text { private } \\
\text { operation }\end{array}$} & \multicolumn{2}{|c|}{$\begin{array}{c}\text { Mixed } \\
\text { construction } \\
\text { and } \\
\text { operation }\end{array}$} & \multicolumn{2}{|c|}{$\begin{array}{c}\text { Government } \\
\text { franchise, } \\
\text { private } \\
\text { investment }\end{array}$} & \multicolumn{2}{|c|}{$\begin{array}{c}\text { Public } \\
\text { construction } \\
\text { and } \\
\text { operation }\end{array}$} & \multicolumn{2}{|c|}{ Other } & Total \\
\hline Testing & $\begin{array}{c}\text { No. } \\
\text { plants }\end{array}$ & $\%$ & $\begin{array}{c}\text { No. } \\
\text { plants }\end{array}$ & $\%$ & $\begin{array}{c}\text { No. } \\
\text { plants }\end{array}$ & $\%$ & $\begin{array}{c}\text { No. } \\
\text { plants }\end{array}$ & $\%$ & $\begin{array}{c}\text { No. } \\
\text { plants }\end{array}$ & $\%$ & $\begin{array}{c}\text { No. } \\
\text { plant } \\
\text { s }\end{array}$ & $\%$ & $\begin{array}{c}\text { No. } \\
\text { plant } \\
\text { s }\end{array}$ \\
\hline $\begin{array}{l}\text { Yes, by } \\
\text { type of } \\
\text { C\&DW } \\
\text { Yes, by } \\
\text { product }\end{array}$ & 10 & 29 & 2 & 50 & 1 & 50 & 1 & 25 & 0 & 0 & 1 & 33 & 15 \\
$\begin{array}{l}\text { No testing } \\
\text { Yes, } \\
\text { product/ } \\
\text { C\&DW } \\
\text { type not } \\
\text { specified }\end{array}$ & 10 & 29 & 1 & 25 & 0 & 0 & 1 & 25 & 1 & 50 & 1 & 33 & 14 \\
No reply & 1 & 3 & 1 & 25 & 0 & 0 & 0 & 0 & 0 & 0 & 0 & 0 & 2 \\
Total & $\mathbf{3 4}$ & $\mathbf{1 0 0}$ & $\mathbf{4}$ & $\mathbf{1 0 0}$ & $\mathbf{2}$ & $\mathbf{1 0 0}$ & $\mathbf{4}$ & $\mathbf{1 0 0}$ & $\mathbf{2}$ & $\mathbf{1 0 0}$ & $\mathbf{3}$ & $\mathbf{1 0 0}$ & $\mathbf{4 9}$ \\
\hline
\end{tabular}


Table 5. Tests conducted on recycled C\&DW

\begin{tabular}{|l|c|c|}
\hline \multicolumn{1}{|c|}{ Test type } & No. plants & $\%$ \\
\hline Grain size distribution & 21 & 63.6 \\
\hline Sand equivalent & 17 & 51.5 \\
\hline $\begin{array}{l}\text { Atterberg limit } \\
\text { Los Angeles coefficient }\end{array}$ & 14 & 42.4 \\
\hline $\begin{array}{l}\text { Flakiness index } \\
\text { Normal or modified Proctor }\end{array}$ & 12 & 36.4 \\
\hline $\begin{array}{l}\text { Organic matter content } \\
\text { Fracture faces } \\
\text { CBR }\end{array}$ & 9 & 27.3 \\
\hline $\begin{array}{l}\text { Soluble salt content } \\
\text { Sulfate content } \\
\text { Chloride content }\end{array}$ & 8 & 24.2 \\
\hline $\begin{array}{l}\text { Acid-soluble sulfate content } \\
\text { Water-soluble sulfate content }\end{array}$ & 7 & 21.2 \\
\hline $\begin{array}{l}\text { Recycled coarse aggregate classification } \\
\text { Natural moisture } \\
\text { Sulfur content }\end{array}$ & 33 & 18.2 \\
\hline $\begin{array}{l}\text { Plaster particle content } \\
\text { Light material content } \\
\text { Clay lump fraction } \\
\text { Failure test } \\
\text { Free swelling } \\
\begin{array}{l}\text { Shape index } \\
\text { Surface dirt }\end{array}\end{array}$ & $\leq 5$ & $\leq 15.2$ \\
\hline Total & & - \\
\hline
\end{tabular}

Table 6. Variation in characteristics over time

\begin{tabular}{|l|c|c|}
\hline Characteristic that varied & No. plants & $\%$ \\
\hline Los Angeles coefficient & 1 & 7.7 \\
Very uniform material & 11 & 84.6 \\
Scantly uniform material & 1 & 7.7 \\
Total & $\mathbf{1 3}$ & $\mathbf{1 0 0}$ \\
\hline
\end{tabular}




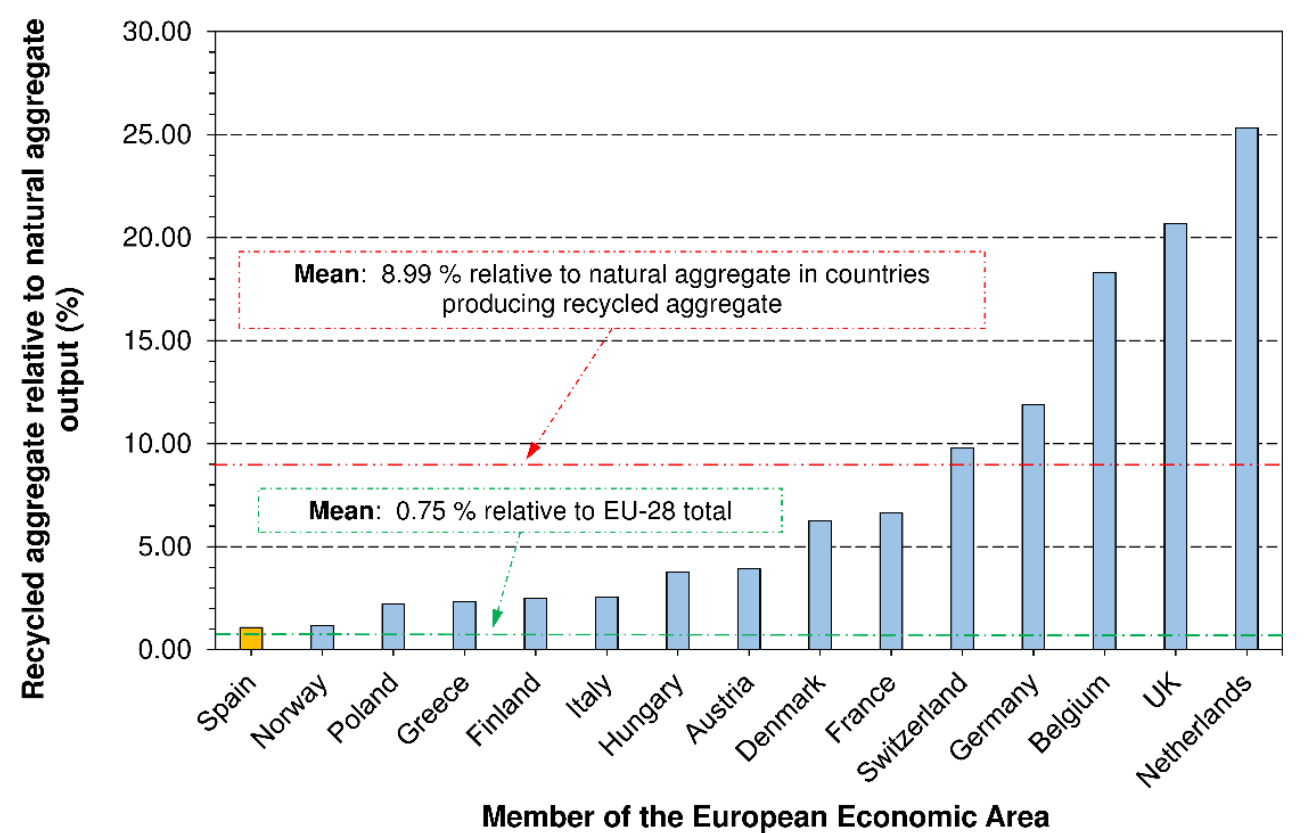

Figure 1. Production of recycled relative to natural aggregate (\%)

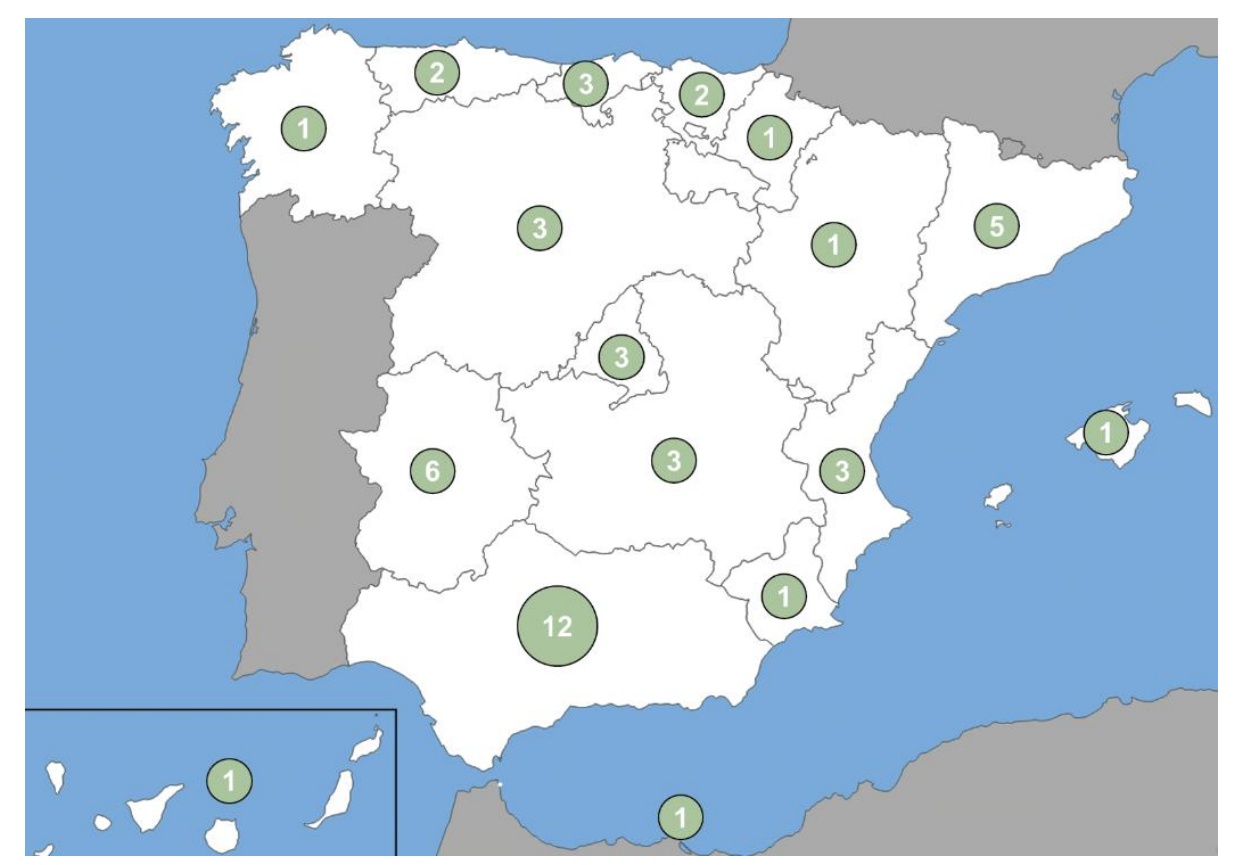

Figure 2. Geographic distribution of respondent facilities 


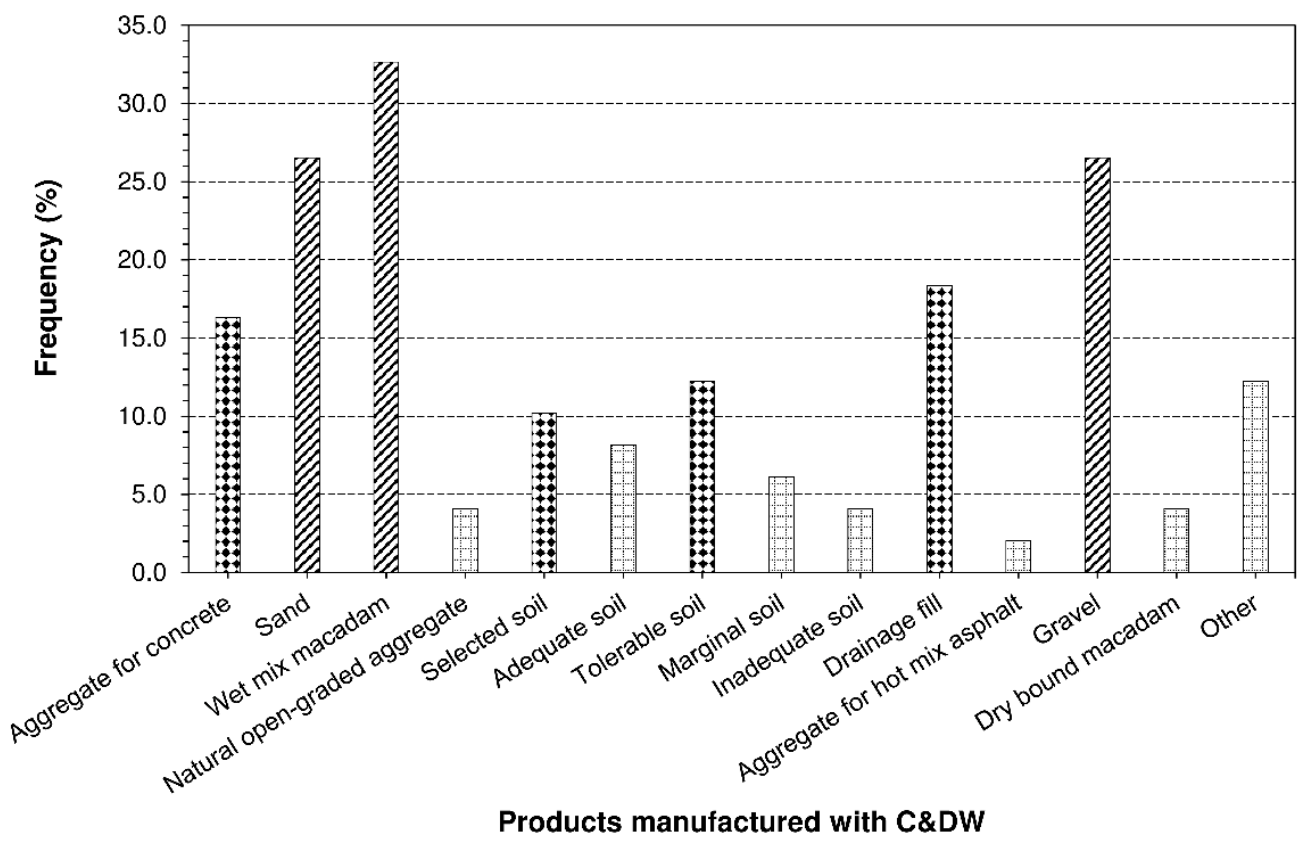

Figure 3. Products manufactured with C\&DW

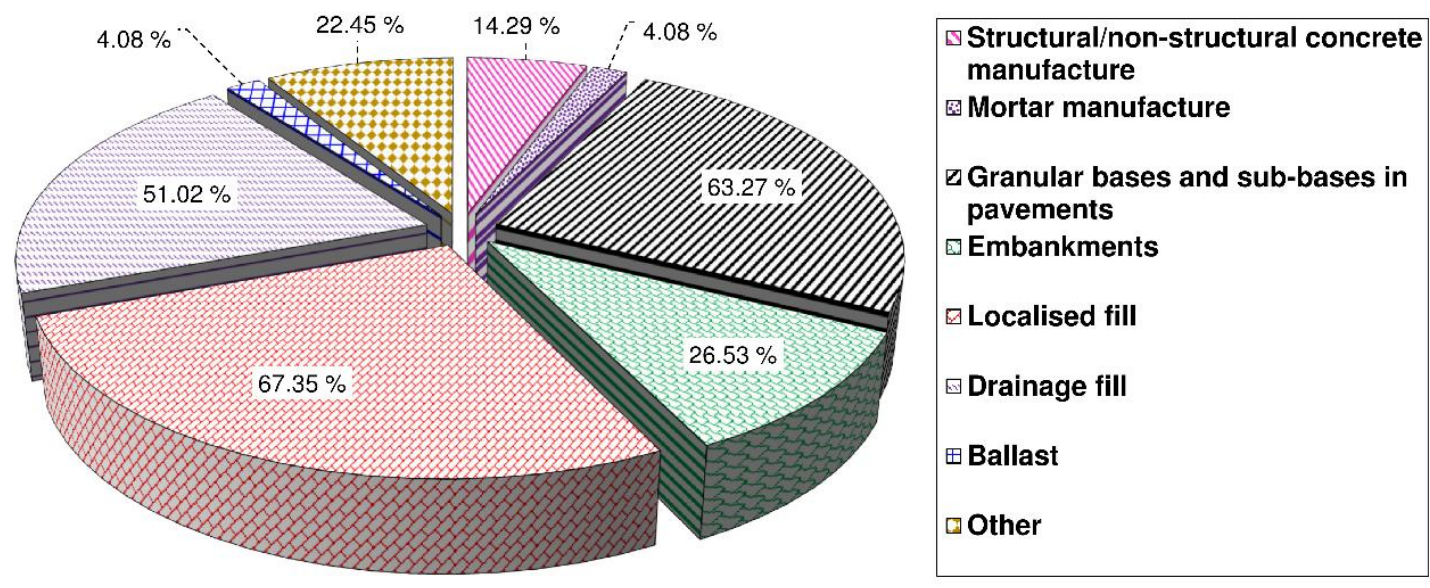

Figure 4. C\&DW-based recycled aggregates: uses 


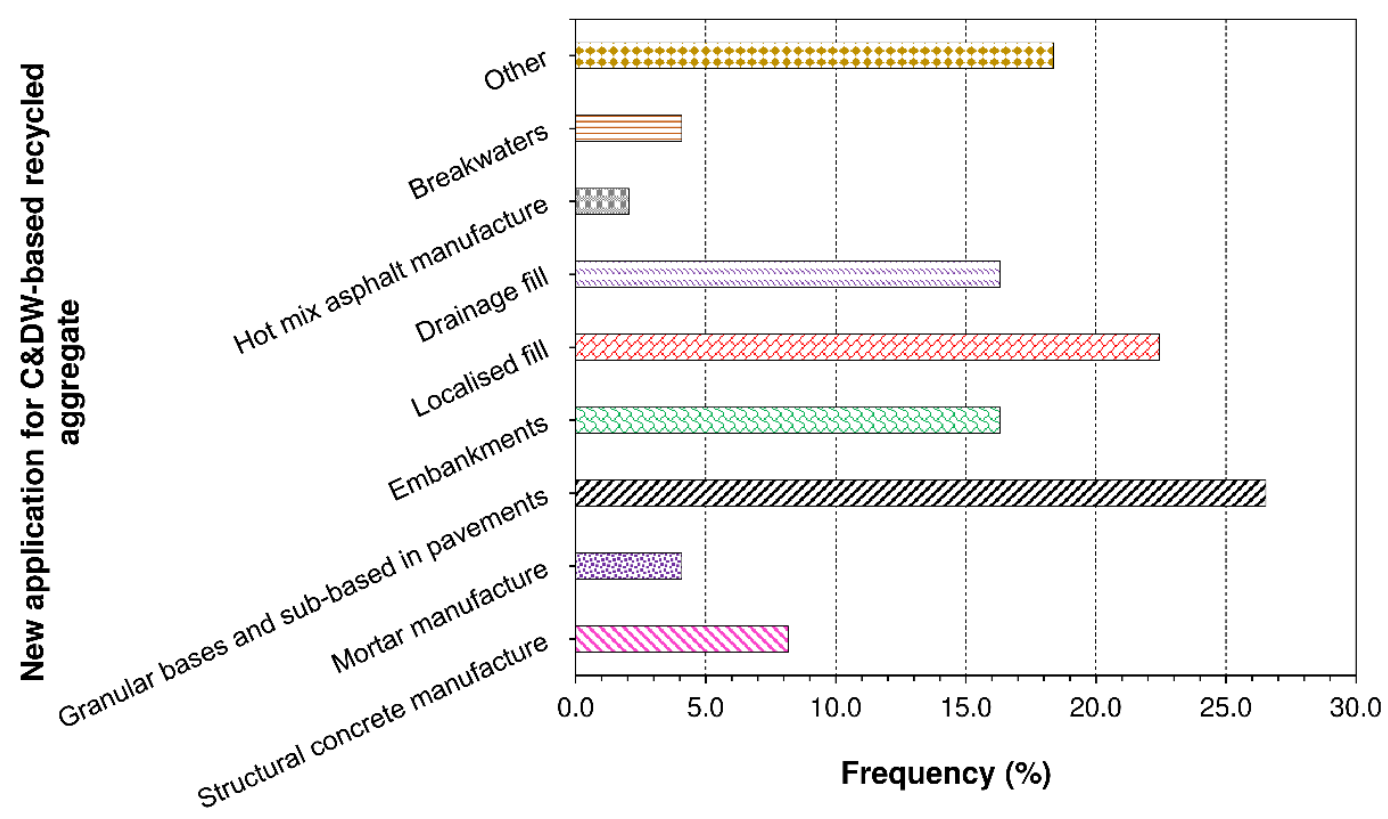

Figure 5. Feasibility of other applications for C\&DW recycled aggregate (the data refer to potential uses identified by respondents, i.e., not in place at the time of the survey; for instance, the four facilities identifying concrete manufacture as a possible application were not included in the seven shown in Figure 3)

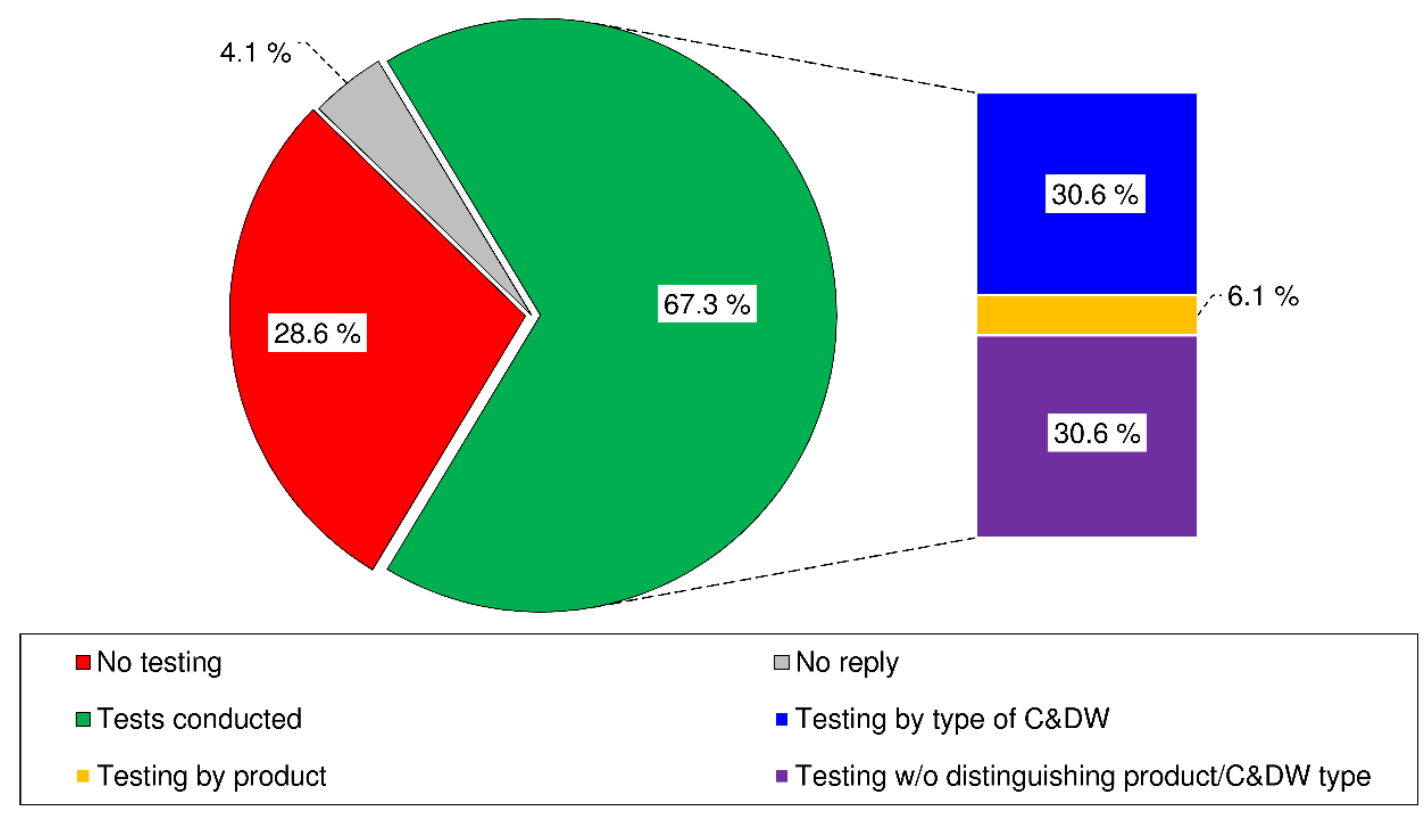

Figure 6. Quality control testing in C\&DW recycling facilities 


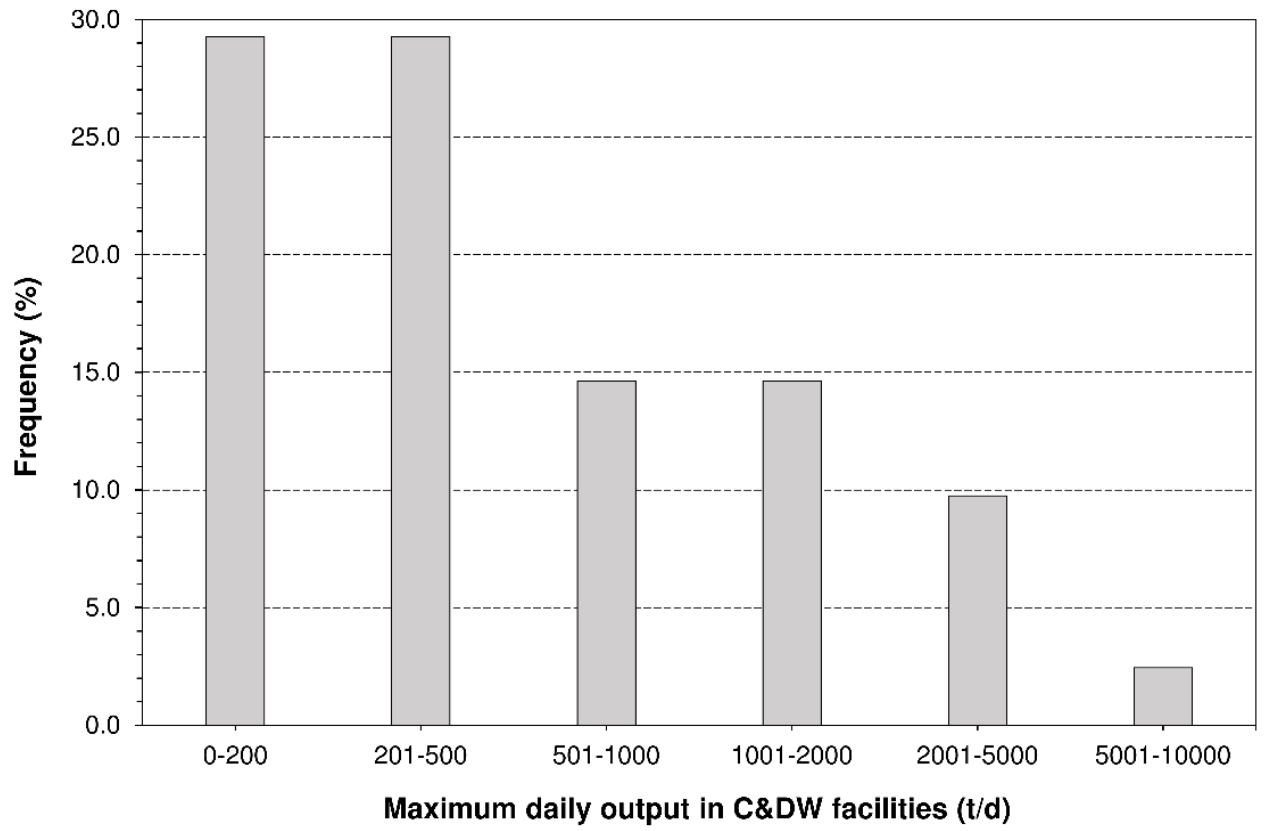

Figure 7. C\&DW facility distribution by daily output (Note: data for 41 respondent facilities) 